\title{
Investigation on fish health and diseases in rural pond aquaculture in three districts of Bangladesh
}

\author{
M. M. Hasan*, M. A. R. Faruk, I. Z. Anka ${ }^{1}$ and M. A. K. Azad ${ }^{2}$ \\ Department of Aquaculture, Bangladesh Agricultural University, Mymensingh-2202, Bangladesh, ${ }^{1}$ Chittagong \\ Veterinary and Animal Sciences University, Chittagong, Bangladesh and ${ }^{2}$ Department of Fisheries, Bangladesh, \\ *E-mail: hasin96@yahoo.com
}

\begin{abstract}
The present study was conducted to know the culture strategies and fish health and disease problems in pond aquaculture in Mymensingh, Bogra and Pabna districts of Bangladesh. Questionnaire interview and participatory rural appraisal tools like focus group discussion (FGD) were conducted with selected fish farmers. In total 90 farmers were interviewed and 9 FGD sessions were conducted. Most of the respondents practiced carp and pangas polyculture and they had disease problems in their ponds. Prevalence of fish disease varied with cultured species and locations. The most prevalent diseases as reported by the farmers were pop eye (57.78\%), ventral reddening (55.55\%), tail and fin rot (48.89), hemorrhagic lesion over the body surface (45.56\%), dropsy (40\%), gill rot (40\%), white spot (40\%) and epizootic ulcerative syndrome or EUS (33.33\%). According to farmers opinion most susceptible species to disease was silver carp, Hypophthalmichthys molitrix (57.78\%); followed by mrigal, Cirrhinus cirrhosus (50\%); catla, Catla catla (47.78\%); sarputi, Barbodes gonionotus (47.78\%); rui, Labio rohita (42.22\%) and pangas, Pangasianodon hypophthalmus (42.22\%). Higher mortality was found in pangas (53.56\%). Clinically, pangas, koi and sarputi were found severely affected. Most of the farmers used some treatment measures against disease problems. This study also highlited some fish health management problems in pond aquaculture. Further studies should include identification and characterization of pathogens involved in different types of diseases in pond aquaculture.
\end{abstract}

Keywords: Fish health and diseases, Rural, Pond aquaculture

\section{Introduction}

Aquaculture in Bangladesh is growing rapidly with respect to both quantity and variety of species. Bangladesh ranked $5^{\text {th }}$ position in leading aquaculture producing countries in the world just after China, India, Vietnam and Indonesia (FAO, 2013). Bangladesh produced 30,61,687 mt fish in 2011 of which $15,23,759 \mathrm{mt}$ i.e. $49.76 \%$ was produced by the aquaculture sector. Bangladesh contributed $2.43 \%$ in world total aquaculture production in 2011 (FAO, 2013). Pond culture represents the mainstay of aquaculture in Bangladesh, accounting for $85.8 \%$ of the total recorded production and $57.7 \%$ of the area under culture (DOF, 2010). Rural pond aquaculture is dominated by the production of Indian major carps and silver carp, grass carp and common carp. About 59\% of the fish produced in rural ponds are Indian major carps. Silver carps are the most important non-native species, accounting for further $19 \%$ of the production. Taken together, carps account for $88 \%$ of the fish recorded as produced in ponds in Bangladesh (DOF, 2010). Nile tilapia (Oreochromis niloticus) and pangasius ( $P$. hypophthalmus) are cultured in ponds mostly as commercial basis by entrepreneurial farmers. Climbing perch (Anabas testudineus) and shing (Heteropneustes fossilis) are also produced in ponds as minor commercial species.

The current trend in aquaculture development is towards increased intensification and commercialization of aquatic production. Like other farming sectors, the likelihood of major disease problems increases as aquaculture activities intensify and expand. Disease is considered as a primary constraint to the culture of many aquatic species, impeding both economic and social development in many countries (Subasinghe et al., 2001). A number of diseases like epizootic ulcerative syndrome, skin erosion, gill damage, tail and fin rot are common in farmed fishes of Bangladesh (Faruk et al., 2004a). In pond aquaculture system, high stocking density and irregularly feed supply is very prone to disease outbreak. Most pond fish farmers do not have a good understanding of health and disease issues in their system. Many diseases of fish are secondary to environmental insult, and can be prevented through proper management. However, there is hardly such scientific information available from which rural pond aqua-farmers could be benefited. The objectives of the present study were therefore to know fish culture strategies and to examine fish disease and health management problems in pond aquaculture through field observation. 


\section{Materials and Methods}

The study focused on three districts namely Mymensingh, Pabna and Bogra of Bangladesh. Data were collected through questionnaire interview and participatory rural appraisal like focus group discussion (FGD) with rural pond fish farmers. For questionnaire survey a set of preliminary questionnaire based on the objectives of the study was prepared. The questionnaire focused mainly on the status of fish farming systems, pond preparation, stocking and pond management, culture species, diseases prevalence, clinical signs, affected species and season, farmer's ability to diagnose disease, fish disease prevention and treatment, health management practices and problems. The questionnaire was composed of both closed and open form of questions. The preliminary questionnaire was tested twice at the field level with few farmers and based on the response, the final set questionnaire was prepared. For the interview, random stratified sampling method was followed. A total of 90 fish farmers (30 farmers from each district) from three districts were interviewed using the questionnaire. The questionnaire was semi-structured and participatory approaches were used all through. Qualitative data was collected through FGD. Nine FGD sessions in three districts were conducted to get an overview of issues fish disease and health management strategies by the farmers. Each group size was between 6 and 12 farmers. Cross check interviews were conducted with key informants. In addition, health condition of fish was also examined clinically by sampling from different ponds in Mymensingh area.

\section{Results}

\section{Fish culture strategy}

All together, data from 90 farmers (30 from each district) were analyzed. Most of them practiced carp (33.33\%) and pangas (60\%) poly culture (Table 1). For carp polyculture, majority of farmers cultured between four and seven fish species in their ponds, which included rui (L. rohita), catla (C. catla), mrigal (C. cirrhosus), silver carp ( $H$. molitrix), carpio (C. carpio), sarputi (Barbodes gonionotus), bata (L. bata) and tilapia (O. nilotica). Pangas ( $P$. hypophthalmus) was the major species in pangas polyculture system along with some carp species. Only 6 farmers in Mymensingh cultured koi.

Table 1. Culture system practiced by pond fish farmers in the study area

\begin{tabular}{|l|c|c|c|c|}
\hline Culture system & $\begin{array}{c}\text { Mymensingh } \\
\mathrm{n}=30\end{array}$ & $\begin{array}{c}\text { Bogra } \\
\mathrm{n}=30\end{array}$ & $\begin{array}{c}\text { Pabna } \\
\mathrm{n}=30\end{array}$ & Percentage \\
\hline Carp polyculture & $12(40.00)$ & $8(26.67)$ & $10(33.33)$ & 33.33 \\
\hline Pangas polyculture & $12(40.00)$ & $22(73.33)$ & $20(66.67)$ & 60.00 \\
\hline Koi monoculture & $6(20.00)$ & 0 & 0 & 6.67 \\
\hline
\end{tabular}

n: Sample size; Figures in parentheses indicate percentage

\section{Stocking density}

Stocking density in pangas polyculture was much higher than carp polyculture. The stocking also varied with districts and it was found highest in Mymensingh and lowest in Pabna (Table 2). It was found that, the stocking density of carp polyculture was maintained at 49091 fry/ha in Mymensingh followed by Bogra (37823.11 fry/ha) and Pabna (10892.7 fry/ha). In pangas polyculture, farmers stocked 74100 fry/ha in Mymensingh whereas it was 42157.96 fry/ha in Bogra and 32171.75 fry/ha in Pabna.

Table 2. Average stocking density of fry

\begin{tabular}{|l|c|c|c|c|}
\hline $\begin{array}{l}\text { Stocking density } \\
\text { (fry/ha) }\end{array}$ & $\begin{array}{c}\text { Mymensingh } \\
\mathrm{n}=30\end{array}$ & $\begin{array}{c}\text { Bogra } \\
\mathrm{n}=30\end{array}$ & $\begin{array}{c}\text { Pabna } \\
\mathrm{n}=30\end{array}$ & $\begin{array}{c}\text { Average } \\
\mathrm{n}=90\end{array}$ \\
\hline Carp polyculture & $49091 \pm 2047.63$ & $37823.11 \pm 2079.74$ & $10892.7 \pm 664.43$ & $32602.35 \pm 19627.14$ \\
\hline Pangas polyculture & $74100 \pm 2610.79$ & $42157.96 \pm 1479.53$ & $32171.75 \pm 1941.42$ & $49476.57 \pm 21901.28$ \\
\hline Koi monoculture & $494000 \pm 135286.84$ & 0 & 0 & $164666.70 \pm 285211$ \\
\hline
\end{tabular}




\section{Fish Production}

Fish production also varied considerably with culture system and areas (Table 3). Production in pangas polyculture was significantly higher than that of carp polyculture. Carp polyculture production was highest in Mymensingh (11690.51 kg/ha) followed by Pabna (14449.5 kg/ha) and Bogra $(11547.25 \mathrm{~kg} / \mathrm{ha})$. Pangas polyculture production was $45290.99 \mathrm{~kg} / \mathrm{ha}$ in Mymensingh, $35533.42 \mathrm{~kg} / \mathrm{ha}$ in Bogra and $40940.25 \mathrm{~kg} / \mathrm{ha}$ in Pabna.

Table 3. Fish production (kg/ha)

\begin{tabular}{|l|l|c|c|c|}
\hline $\begin{array}{l}\text { Production } \\
(\mathrm{kg} / \mathrm{ha})\end{array}$ & \multicolumn{1}{|c|}{$\begin{array}{c}\text { Mymensingh } \\
\mathrm{n}=30\end{array}$} & $\begin{array}{c}\text { Bogra } \\
\mathrm{n}=30\end{array}$ & $\begin{array}{c}\text { Pabna } \\
\mathrm{n}=30\end{array}$ & $\begin{array}{c}\text { Average } \\
\mathrm{n}=90\end{array}$ \\
\hline Carp polyculture & $11690.51 \pm 1995.76$ & $11547.25 \pm 1852.5$ & $14449.5 \pm 2808.39$ & $12562.42 \pm 1635.83$ \\
\hline Pangas polyculture & $45695 \pm 3453.06$ & $35533.42 \pm 7827.43$ & $40940.25 \pm 9339.07$ & $40722.89 \pm 5084.28$ \\
\hline Koi monoculture & $41290.99 \pm 1264.64$ & 0 & 0 & $13763.66 \pm 3839.36$ \\
\hline
\end{tabular}

Three types of pond ownership were observed for fish culture which included farmers own pond (42.22\%), leased (20\%) and both own and leased (37.78\%) (Table 4). The average number of pond per farmer was 3.4 with an average area of 0.7 ha and depth $1.4 \mathrm{~m}$ (Table 5). The average pond area in Borga was much bigger than that of Pabna and Mymensingh.

Table 4. Fish culture pond ownership (\%) pattern in the study area

\begin{tabular}{|c|c|c|c|c|}
\hline Ownership & $\begin{array}{c}\text { Mymensingh } \\
\mathrm{n}=30\end{array}$ & $\begin{array}{c}\text { Bogra } \\
\mathrm{n}=30\end{array}$ & $\begin{array}{c}\text { Pabna } \\
\mathrm{n}=30\end{array}$ & $\begin{array}{c}\text { Overall Average } \\
(\%)\end{array}$ \\
\hline Owned & $23(76.67)$ & $8(26.67)$ & $7(23.33)$ & 42.22 \\
\hline Leased & $4(13.33)$ & $2(6.67)$ & $12(40.00)$ & 20.00 \\
\hline Owned + leased & $3(10.00)$ & $20(66.67)$ & $11(36.67)$ & 37.78 \\
\hline
\end{tabular}

$n$ : Sample size; figures in parentheses indicate percentage

Table 5. Average pond number, area and depth in the study area

\begin{tabular}{|l|c|c|c|c|}
\hline Pond description & $\begin{array}{c}\text { Mymensingh } \\
\mathrm{n}=30\end{array}$ & $\begin{array}{c}\text { Bogra } \\
\mathrm{n}=30\end{array}$ & $\begin{array}{c}\text { Pabna } \\
\mathrm{n}=30\end{array}$ & Overall Average (\%) \\
\hline No of pond & $3.1 \pm 1.6$ & $3.6 \pm 0.97$ & $3.5 \pm 1.31$ & $3.4 \pm 0.27$ \\
\hline Pond area (ha) & $0.38 \pm 0.18$ & $1.08 \pm 1.08$ & $0.65 \pm 0.34$ & $0.7 \pm 0.35$ \\
\hline Pond depth (m) & $1.13 \pm 0.34$ & $1.63 \pm 0.32$ & $1.43 \pm 0.18$ & $1.4 \pm 0.25$ \\
\hline
\end{tabular}

Majority of the ponds (96.67\%) were perennial and only 3.3\% were seasonal. All the ponds both in Bogra and Pabna were perennial and they used deep tube-well water for fish culture. In Mymensingh, 60\% ponds used deep tube-well water and $40 \%$ were seasonal. The majority of the ponds $(75.56 \%)$ have water inlet and outlet system.

\section{Fish disease and health management}

Most of the farmers (95.56\%) monitor the health of fish either weekly or monthly. Farmers mentioned a number of diseases and conditions which they could recognized clinically. The most prevalent clinical signs of disease were pop eye (57.78\%), ventral reddening (55.55\%), tail and fin rot (48.89), haemorrhagic lesion over body surface (45.56\%), dropsy (40\%), gill rot (40\%) white spot (40\%) and epizootic ulcerative syndrome or EUS (33.33\%) (Table 6). Other conditions like red spot, scale erosion, argulosis, mouth reddening, haemorrhagic eyes, rectal protrusion and malnutrition were also mentioned by the farmers but with lower incidences. Some of the clinical signs were confirmed during collection of diseased fish for histopathological studies. 
Table 6. Types of fish diseases (\%) in pond aquaculture in the study area

\begin{tabular}{|l|c|c|c|c|}
\hline Disease name & $\begin{array}{c}\text { Mymensingh } \\
\mathrm{n}=30\end{array}$ & $\begin{array}{c}\text { Bogra } \\
\mathrm{n}=30\end{array}$ & $\begin{array}{c}\text { Pabna } \\
\mathrm{n}=30\end{array}$ & Overall Average (\%) \\
\hline Pop eye & $15(50.00)$ & $21(70.00)$ & $16(53.33)$ & 57.78 \\
\hline Ventral reddening & $12(40.00)$ & $22(73.33)$ & $16(53.33)$ & 55.55 \\
\hline Tail and fin Rot & $17(56.67)$ & $18(60.00)$ & $9(30.00)$ & 48.89 \\
\hline Haemorrhage & $12(40.00)$ & $20(66.67)$ & $9(30.00)$ & 45.56 \\
\hline Gill Rot & $7(23.33)$ & $17(56.67)$ & $12(40.00)$ & 40.00 \\
\hline Dropsy & $8(26.67)$ & $13(43.33)$ & $15(50.00)$ & 40.00 \\
\hline White Spot & $7(23.33)$ & $15(50.00)$ & $14(46.67)$ & 40.00 \\
\hline EUS & $14(46.67)$ & $13(43.33)$ & $3(10.00)$ & 33.33 \\
\hline Red Spot & $16(53.33)$ & $2(6.67)$ & $3(10.00)$ & 23.33 \\
\hline Scale erosion & $10(33.33)$ & $5(16.67)$ & $3(10.00)$ & 20.00 \\
\hline Argulosis & $2(6.67)$ & $10(33.33)$ & $4(13.33)$ & 17.78 \\
\hline Mouth Reddening & $5(16.6)$ & $10(33.33)$ & $1(3.33)$ & 17.78 \\
\hline Haemorrhagic eye & $3(10.00)$ & $10(33.33)$ & 0 & 14.44 \\
\hline Enlarged jaw & 0 & 0 & $12(40.00)$ & 13.33 \\
\hline Rectal protrusion & 0 & $11(36.67)$ & 0 & 12.22 \\
\hline Mal nutrition & $6(20.00)$ & $4(13.33)$ & 0 & 11.11 \\
\hline
\end{tabular}

$n$ : Sample size; figures in parentheses indicate percentage

\section{Disease affected species}

Most susceptible species to disease was silver carp (57.78\%), followed by mrigal (50\%), catla (47.78\%), sarputi $(47.78 \%)$, rui $(42.22 \%)$ and pangas (42.22\%) (Table 7). Other species were also found susceptible but the rate was very low.

Table 7. Disease affected fish (\%) in pond aquaculture in the study area

\begin{tabular}{|l|c|c|c|c|}
\hline Name of diseased fish & $\begin{array}{c}\text { Mymensingh } \\
\mathrm{n}=30\end{array}$ & $\begin{array}{c}\text { Bogra } \\
\mathrm{n}=30\end{array}$ & $\begin{array}{c}\text { Pabna } \\
\mathrm{n}=30\end{array}$ & $\begin{array}{c}\text { Overall Average } \\
(\%)\end{array}$ \\
\hline Silver carp & $15(50.00)$ & $21(70.00)$ & $16(53.33)$ & 57.78 \\
\hline Mrigal & $15(50.00)$ & $18(60.00)$ & $12(40.00)$ & 50.00 \\
\hline Catla & $12(40.00)$ & $16(53.33)$ & $15(50.00)$ & 47.78 \\
\hline Sarputi & $14(46.67)$ & $22(73.33)$ & $7(23.33)$ & 47.78 \\
\hline Rohu & $18(60.00)$ & $20(66.67)$ & 0 & 42.22 \\
\hline Pangas & $8(27.67)$ & $15(50.00)$ & $15(50.00)$ & 42.22 \\
\hline Bata & $1(3.33)$ & $7(23.33)$ & $10(33.33)$ & 19.99 \\
\hline Koi & $7(23.33)$ & $2(6.67)$ & $1(3.33)$ & 11.11 \\
\hline Tilapia & $2(6.67)$ & $5(16.67)$ & $1(3.33)$ & 8.89 \\
\hline Carpio & $5(16.67)$ & $3(10)$ & 0 & 8.89 \\
\hline Shing & $7(23.33)$ & 0 & 0 & 7.78 \\
\hline Magur & $4(13.33)$ & 0 & 0 & 4.44 \\
\hline Gulsha & $2(6.67)$ & 0 & 0 & 2.22 \\
\hline
\end{tabular}

$n$ : Sample size; figures in parentheses indicate percentage

\section{Clinical signs of disease affected fish}

A number of clinical signs were noticed during clinical diagnosis of sampled fishes. Clinically pangas, koi and sarputi were found severely affected (Fig. 1). Pangas exhibited pop eye, reddish discoloration around mouth and eye, anal protrusion and hemorrhagic caudal fin. Massively affected koi were seen showing clinical signs of deep hemorhagic ulcerative lesion over body surface with tail rot. Large hemorrhagic ulcerative lesion on caudal region, severe scale loss and hemorrhage over the body surface and at the base of fin were observed in sarputi. Scale loss, marked hemorrhagic lesion over the surface and ventral part of the body were seen in mrigal. Catla showed clinical signs which include scale loss, hemorrhagic 
lesion on body surface along with anal protrusion. Scale loss and hemorrhagic lesion on caudal region were noticed in rui. Silver carp were found to have clinical signs including hemorrhagic lesion on body surface, hemorrhagic fin, mouth and caudal region along with arrow head. Scale loss, hemorrhagic lesion over the surface and ventral part of the body, hemorrhagic anal and caudal fin were observed in carpio. A large number of clinical signs were also reported by the farmers which could not be seen during diagnosis. The clinical signs were described here mostly based on sampled diseased fishes.
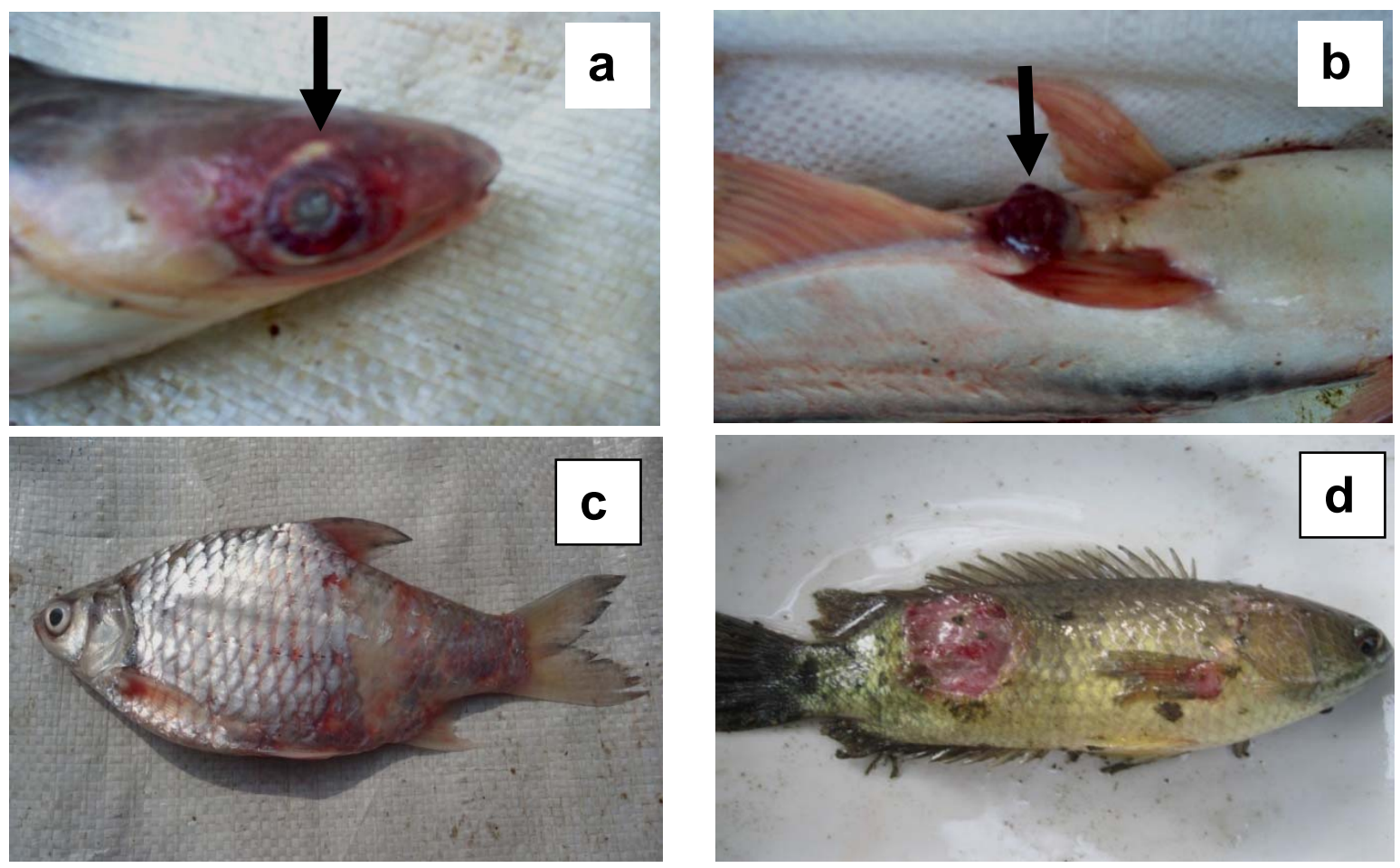

Fig. 1. Clinically diseased fishes sampled from farmers pond in Mymensingh. (a) Pangas (Pangasianodon hypophthalmus) with pop eye and reddish discoloration around the mouth and eye. (b) Pangas with rectal protrusion; (c) Sarputi (Barbodes gonionotus) exhibited haemorrhagic ulcerative lesion on caudal region and haemorrhage at the base of fin (d) Koi (Anabas testudineus) with deep haemorrhagic ulcerative lesion on tail region.

\section{Mortality of fish due to disease}

Of the disease affected fishes, the mortality of pangas was found to very high (53.56\%) compared to carps like rui, catla, mrigal and silver carp (Table 8).

Table 8. Mortality (\%) of fish due to disease in various ponds in the study area

\begin{tabular}{|c|c|c|c|c|}
\hline Fish Species & Mymensingh & Bogra & Pabna & Average (\%) \\
\hline Carps & 41.34 & 15.11 & 4.56 & 20.34 \\
\hline Pangas & 35.00 & 82.89 & 42.78 & 53.56 \\
\hline Koi & 32.44 & 0 & 0 & 10.81 \\
\hline
\end{tabular}

\section{Disease occurring season}

Farmers were asked in which season of the year they noticed these diseases, about $73.34 \%$ farmer reported that they found most of the diseases during winter season, $18.89 \%$ reported later winter and $7.78 \%$ reported early winter (Table 9 ). 
Table 9. Disease occurring season (\%) in the study area

\begin{tabular}{|c|c|c|c|c|}
\hline Season & $\begin{array}{c}\text { Mymensingh } \\
\mathrm{n}=30\end{array}$ & $\begin{array}{c}\text { Bogra } \\
\mathrm{n}=30\end{array}$ & $\begin{array}{c}\text { Pabna } \\
\mathrm{n}=30\end{array}$ & $\begin{array}{c}\text { Average } \\
\mathrm{n}=90\end{array}$ \\
\hline Early winter & 13.33 & 10 & 0 & 7.78 \\
\hline Winter & 76.67 & 76.67 & 66.67 & 73.34 \\
\hline Late winter & 20 & 20 & 16.67 & 18.89 \\
\hline
\end{tabular}

\section{Frequency of disease occurrence}

Majority $(67.78 \%)$ of the farmers mentioned that they noticed diseases in their ponds once in a year. However, $20 \%$ noticed 1-2 times while few others found 3-4 times in a year (Table 10). Farmers in Pabna noticed fish disease in their pond only once in a year.

Table 10. Frequency of disease occurrence

\begin{tabular}{|c|c|c|c|c|}
\hline Frequency/year & $\begin{array}{c}\text { Mymensingh } \\
\mathrm{n}=30\end{array}$ & $\begin{array}{c}\text { Bogra } \\
\mathrm{n}=30\end{array}$ & $\begin{array}{c}\text { Pabna } \\
\mathrm{n}=30\end{array}$ & $\begin{array}{c}\text { Average } \\
\mathrm{n}=90\end{array}$ \\
\hline 1 & 43.33 & 83.33 & 76.67 & 67.78 \\
\hline $1-2$ & 40 & 20 & 0 & 20.00 \\
\hline $3-4$ & 6.67 & 20 & 0 & 8.89 \\
\hline
\end{tabular}

\section{Health management strategies}

Generally, affected farmers turned to other experienced farmers for advice when for fish health management suggesting and disease treatment. It was found that they applied some traditional treatments. Liming (83.33\%) and application of salt (82.22\%) in pond were the most common treatment followed by use of antibiotics, potassium permanganate and copper sulphate (Table 11).

Table 11. Fish health management and treatment measures

\begin{tabular}{|l|c|c|c|c|}
\hline Measures & Mymensingh & Bogra & Pabna & Overall (\%) \\
\hline Lime & $19(63.33)$ & $30(100)$ & $26(86.67)$ & 83.33 \\
\hline Salt & $20(66.67)$ & $29(96.67)$ & $25(83.33)$ & 82.22 \\
\hline Antibiotics & $10(33.33)$ & $25(83.33)$ & $13(43.33)$ & 53.33 \\
\hline Vitamins & $7(23.33)$ & $22(73.33)$ & $13(43.33)$ & 46.66 \\
\hline Potassium permenganate & $7(23.33)$ & $5(16.67)$ & $8(26.67)$ & 22.22 \\
\hline Copper sulphate & $2(6.67)$ & $13(43.33)$ & 0 & 16.67 \\
\hline No treatment & $5(16.67)$ & 0 & $1(3.33)$ & 6.67 \\
\hline
\end{tabular}

n: Sample size; figures in parentheses indicate percentage

\section{Assistance for health management}

Assistance of fish farmers on disease prevention and health management from non-governmental organization (NGOs) and government extension officers rarely assisted. Only $6.67 \%$ farmers got some sort of advice either from GO or NGO. There were also severe under reporting of diseases by the farmers. Farmers hardly go to the Upazila Fisheries Officer (UFO) to inform any disease problem or for advice.

\section{Major fish health management problems}

During different FGDs, the present study identified some fish health management problems faced by pond farmers which included poor knowledge about fish health management, disease diagnosis problem, lack of bio-security measure in farms, lack of assistance regarding fish disease treatment, and lack of appropriate therapeutics and methods of their application. 


\section{Discussion}

Pond aquaculture shares the major portion in total aquaculture production in the country. In the present study, it was found that pond culture was dominated by polyculture of carps and pangas. For carp polyculture majority of farmers practiced between four or seven carp species in their pond. In pangas polyculture major species was pangas along with some carp species. Stocking density was found varied with the culture strategy and with study area. It was much higher in pangas polyculture than carp polyculture and was found the highest in Mymensingh and the lowest in Pabna. To get more production farmers usually maintained high stocking density in this culture system. The stocking density of carp and pangas polyculture was much higher in Mymensingh which was 49091 fry/ha and 74100 fry/ha respectively. Monir (2009) reported that farmers stocked 42,595 pangas fry/ha and 17,088/ha carps in pangas polyculture ponds. Belton et al. (2011) reported a stocking density of pangas in polyculture system as $6 \mathrm{fry} / \mathrm{m}^{2}$ where in Vietnam it was $44 \mathrm{fish} / \mathrm{m}^{2}$.

Fish production also varied considerably with culture system and areas. Total fish production in pangas polyculture was higher than carp polyculture. This might be due to the intensive culture system of pangas. Overall management in pangas polyculture pond was much better than that of carp. Regular feeding and health checking of pangas were also a causal factor of higher production. Pond size and depth were also varied among districts and it was found that higher in Bogra followed by Pabna and Mymensingh. Fish production in larger pond was comparatively lower than smaller one.

Proper pond management and regular health checking of fish are essential for successful fish culture. Larger pond area was the major limiting factor of satisfactory production. Farmers could not manage and monitor their fish pond properly in Bogra due to large pond area. Consequently, fish production in both culture systems was higher in Mymensingh district due to having small pond area which was easily manageable. In this region, pangas and carp polyculture production were found as $45290.99 \mathrm{~kg} / \mathrm{ha}$ and $11690.51 \mathrm{~kg} / \mathrm{ha}$ respectively. Edwards and Hossain (2010) reported the production of pangas as 60-70 MT /ha by commercial farmers where it was $40 \mathrm{MT} / \mathrm{ha}$ by small farms. Although this production seems quite good for Bangladesh but still it is far less than the production in Vietnam. In intensive system Vietnam produces around $700 \mathrm{MT} /$ ha/years (NACA, 2009).

The present study identified the fish health and clinical signs of disease condition in pond aquaculture in Bangladesh. Pop eye, ventral reddening, tail and fin rot, haemorrhagic lesion over body surface, dropsy, gill rot, white spot and EUS were found as the most prevalent clinical signs of disease. Chowdhury (1998) mentioned that the common diseases of freshwater fishes of Bangladesh were tail and fin rot, bacterial gill rot, dropsy, various types of fungal diseases, protozoan diseases, parasitic diseases, nutritional disease, and various tumors. Similar observation was also made by Faruk et al. (2008). Brown and Brooks (2002) mentioned that in their study farmers were capable of identifying at most nine major causes of fish death in their ponds. The most common cause of death were red spot disease referred to as EUS, fin rot, air gulfing and cotton fungus.

In the present study it was observed that most susceptible species to disease was silver carp followed by mrigal, catla, sarputi, rui and pangas. Mortality of pangas was comparatively higher than carp species. According to fish farmers, most of the diseases mainly occurred during the winter season. During this time water level of farmer's pond become very low and the water quality also become very poor. Fish take less food at this time and their physiological condition become gradually weak leading fish more susceptible to disease. Therefore, farmers could be suggested to take some preventive measures at the beginning of the winter season which include, application of lime and salt, disinfecting of equipment, addition of water, etc. (Faruk et al., 2004b).

The diseases reported by fish farmers was found very high which is due to the lack awareness of farmers about fish disease and also lack of reporting places or diagnostic laboratory from where farmers can get advice and other support services. As a consequence there were severe lack of prevention, diagnosis and treatment. In the present study, farmers were found to apply some traditional treatments. Application of lime and salt in pond were the most common treatment followed by use of antibiotics, potassium permanganate and copper sulphate. Faruk et al. (2004b) reported that $46 \%$ farmers used combination of lime and potassium permanganate, $22.4 \%$ farmers used only lime and $10 \%$ farmer used lime and salt together for treating disease. 


\section{Conclusion}

Aquaculture activities in Bangladesh are predominantly pond based. The present study provided valuable information regarding fish disease problems in rural pond aquaculture. All the infectious diseases reported here by the farmers could not be confirmed by laboratory study. It would have been better if laboratory diagnosis could be performed to identify and characterize the pathogens involved in different types of diseases. Also, there is a need to train farmers on simple diagnostic procedure and effective therapy. It is also important to establish fish disease diagnostic clinic to provide assistance to farmers on fish health management.

\section{Acknowledgements}

The authors are grateful to the Bangladesh Agricultural Research Council (BARC) for providing financial support to the project through Bangladesh Agricultural Research system (BAURES). The authors are also thankful to all the fish farmers for participating in the interview and FGD sessions.

\section{References}

Belton, B. Haque, M.M., Little, D.C. and Sinth, L.X. 2011. Certifying catfish in Vietnam and Bangladesh: Who will make grade and will it matter? Food Policy, 36: 289-299.

Brown, D. and Brooks, A. 2002. A survey of disease impact and awareness in pond aquaculture in Bangladesh, the Fisheries and Training Extension Project- Phase 11. In J.R. Arther, M.J. Phillips, R.P. Subasinghe, M.B. Reantaso and I.H. MacRae (Eds), Primary Aquatic Animal Health Care in Rural, Small-Scale and Aquaculture Development. FAO Fisheries Technical Paper No. 406, pp. 85-93.

Chowdhury, M.B.R. 1998. Involvement of aeromonad and pseudomonads in diseases of farmed fish in Bangladesh. Fish Pathology, 33: $247-254$.

DoF, 2010. Department of Fisheries, Fishery Statistical Yearbook of Bangladesh 2008-2009, Vol. 26, No. 1. Fisheries Resources Survey System, Ministry of Fisheries and Livestock, Dhaka, Bangladesh.

Edwards, P. and Hossain, M.S. 2010. Bangladesh seeks export markets for striped catfish. Global aquaculture advocate May/June, 2010.

FAO, 2013. Fisheries and Aquaculture Department, Global Aquaculture Production Statistics for the year 2011. $\mathrm{ftp}: / / \mathrm{ftp}$. fao.org/Fl/news/ GlobalAquacultureProductionStatistics2011.pdf

Faruk, M.A.R., Sarker, M.M.R., Alam, M.J. and Kabir, M.B. 2004a. Economic loss from fish diseases on rural freshwater aquaculture of Bangladesh. Pakistan Journal of Biological Sciences, 7(12): 2086-2091.

Faruk, M.A.R., Alam, M.J., Sarker, M.M.R. and Kabir, M.B. 2004b. Status of fish disease and health management practices in rural freshwater aquaculture of Bangladesh. Pakistan Journal of Biological Sciences, 7(12): 2092-2098.

Faruk, M.A.R., Ali, M.M. and Patwary, Z.P. 2008. Evaluation of the status of use of chemicals and antibiotics in freshwater aquaculture activities with special emphasis to fish health management. Journal of Bangladesh Agricultural University, 6(2): 381-390.

Monir, S.A.M. 2009. Socio-economic Impacts and Sustainability of Pangusius (Pangasianodon hypophthalmus) farming in Trishal Upazila, Mymensingh, Bangladesh, M.S. Thesis, Department of Aquaculture, Bangladesh Agricultural University, Mymensingh, Bangladesh.

NACA, 2009. Better management practices (BMPs) for striped catfish (tra catfish) farming practices in the Mekong Delta. $<$ http://library.enaca. org/inland/projects/draft-catfish-bmps-09.pdf

Subasinghe, R.P., Bondad-Reantaso, M.G. and McGladdery, S.E. 2001. Aquaculture development, health and wealth. In R.P. Subasinghe, P. Bueno, M.J. Phillips, C. Hough, S.E. McGladdery and J.R. Arthur (Eds), Aquaculture in the Third Millennium. Technical Proceedings of the Conference on Aquaculture in the Third Millennium, Bangkok, Thailand, 20-25 February 2000, NACA, Bangkok and FAO, Rome. pp. 167-191. 